\title{
KINERJA KOMISI PEMILIHAN UMUM DALAM MENINGKATKAN PARTISIPASI MASYARAKAT PENDATANG PADA PILPRES 2019 DI KOTA MAKASSAR PROVINSI SULAWESI SELATAN
}

\author{
Oleh \\ Andi Tenri Chahya Sari Entong ${ }^{1}$, \\ Ngadisah $^{2}$, Diah Anggraeni ${ }^{3}$ \\ 1) Badan Penelitian dan Pengembangan Kemendagri \\ Program Magister Terapan Studi Pemerintahan Daerah Institut Pemerintahan Dalam Negeri \\ andi.endi94@gmail.com \\ ${ }^{2,3)}$ Institut Pemerintahan Dalam Negeri
}

\begin{abstract}
$T$ 2019 Presidential Election is the implementation of the Fourth Presidential Election which directly elected by the people on principle of direct, public, free, confidential, honest and fair and must fulfill the principles of being independent, honest, fair, having legal certainty, orderly, being open, proportional, professional, accountable, effective and efficient. This study aims to determine and to analyze the performance of General Election Commission in Makassar City in increasing the participation of the immigrant communities in the 2019 Presidential Election. What factors influence the performance of the General Election Commission of Makassar City in increasing the participation of immigrant communities in the 2019 Presidential Election and the efforts to overcome the obstacles to increase the participation the immigrant communities in the 2019 Presidential Election. Various problems include the lack of socialization, the numbers of personnel are not comparable to the community, the limited of time and the lack of ballots. As a theoretical basis used the theory of performance proposed by Agus Dwiyanto (2008: 50-51). The object of research is the General Election Commission of Makassar, by a qualitative approach with interview methods and secondary data or literature studies from various relevant scientific references used to support primary data analysis. The results showed that the performance of the General Election Commission of Makassar City in increasing the participation of immigrant communities in the 2019 Presidential Election was quite good, it was indicated by the level of participation of the immigrant communities $84.02 \%$, but it still needed to be increased again in the socialization so that the target of immigrant community in the 2024 Presidential Election will reach $100 \%$ in Makassar City.
\end{abstract}

Keywords: performance; participation; migrant communities

\begin{abstract}
Abstrak
$P$ lpres 2019 merupakan pelaksanaan Pilpres Ke IV yang dipilih secara langsung oleh rakyat dengan asas langsung, umum, bebas, rahasia, jujur dan adil serta harus memenuhi prinsip mandiri, jujur, adil, berkepastian hukum, tertib, terbuka, proporsional, profesional, akuntabel, efektif dan efisien. Penelitian ini bertujuan untuk mengetahui dan menganalisis kinerja KPU Kota Makassar dalam Meningkatkan partisipasi masyarakat pendatang pada Pilpres 2019,
\end{abstract}


faktor-faktor apa yang menghambat kinerja KPU Kota Makassar dalam Meningkatkan partisipasi masyarakat pendatang pada Pilpres 2019 dan upaya yang dilakukan KPU Kota Makassar dalam Meningkatkan partisipasi masyarakat pendatang pada Pilpres 2019. Berbagai permasalahan di antaranya kurangnya sosialisasi, jumlah personel yang tidak sebanding dengan masyarakat, dan data masyarakat pendatang belum sinkron dengan data dukcapil/SIAK. Sebagai landasan teori digunakan teori kinerja yang dikemukakan oleh Agus Dwiyanto (2008:50-51). Objek penelitian adalah KPU Kota Makassar, melalui pendekatan kualitatif dengan metode wawancara dan digunakan data sekunder atau studi kepustakaan dari berbagai referensi ilmiah yang relevan untuk mendukung analisis data primer. Hasil penelitian menunjukkan bahwa Kinerja KPU Kota Makassar dalam Meningkatkan partisipasi masyarakat pendatang pada Pilpres 2019 cukup baik, ditunjukkan dengan tingkat partisipasi masyarakat pendatang 84,02\%, namun masih perlu ditingkatkan lagi dalam sosialisasi agar target masyarakat pendatang pada Pilpres 2024 mencapai $100 \%$ di Kota Makassar.

Kata kunci: kinerja, partisipasi, masyarakat pendatang

\section{PENDAHULUAN}

Demilu dilaksanakan berdasarkan asas langsung, umum, bebas, rahasia, jujur dan adil. Dalam penyelenggaraannya, pemilu harus Berdasarkan pada asas sebagaimana dimaksud, dan harus memenuhi prinsip mandiri, jujur, adil, berkepastian hukum, tertib, terbuka, proporsional, profesional, akuntabel, efektif dan efisien. Khusus Pilpres, dijelaskan lebih lanjut secara rinci mengenai syarat dan proses pelaksanaannya dalam Undang-Undang Nomor 42 Tahun 2008 tentang Pemilihan Umum Presiden dan Wakil Presiden.

Pilpres 2019 merupakan pelaksanaan Pilpres keempat yang dipilih secara langsung oleh rakyat. Pilpres pertama dilaksanakan pada 20 Oktober 2004 dan dimenangkan oleh pasangan Susilo Bambang Yudhoyono dan Jusuf Kalla. Pilpres kedua diselenggarakan pada 8 Juli 2009 dan dimenangkan oleh pasangan Susilo Bambang Yudhoyono dan Boediono. Pilpres ketiga diselenggarakan pada 9 Juli 2014 dan dimenangkan oleh pasangan Joko Widodo dan Jusuf Kalla. Pilpres keempat dilaksanakan pada 17 April 2019 dan dimenangkan oleh pasangan Joko Widodo dan Ma'ruf Amin.

Pelaksanaan Pemilu sangat erat kaitannya dengan masyarakat yang tercantum sebagai Daftar Pemilih yang akan menggunakan hak pilihnya agar terpilih Presiden dan Wakil Presiden berdasarkan suara terbanyak. Peraturan KPU Nomor 11 Tahun 2018 tentang Penyusun Daftar Pemilih di Dalam Negeri Dalam Penyelenggaraan Pemilihan Umum Pasal 1 Ayat 37 menyebutkan bahwa "Daftar Pemilih Tambahan yang selanjutnya disingkat DPTb adalah Daftar Pemilih yang telah terdaftar dalam DPT di suatu TPS yang karena keadaan tertentu Pemilih tidak dapat menggunakan haknya untuk memilih di TPS tempat yang bersangkutan terdaftar dan memberikan suara di TPS lain". Sehingga dapat diketahui, apabila masyarakat pendatang ingin tetap menggunakan hak pilihnya bisa melakukan pendaftaran melalui KPU setempat dengan batas waktu paling lambat 30 (tiga puluh) hari sebelum hari pemungutan suara sesuai Undang-Undang Nomor 7 Tahun 2017 tentang Pemilu Pasal 210 ayat (1).

Pelaksanaan Pilpres di Kota Makassar dilaksanakan sesuai dengan jadwal Pilpres Serentak pada 17 April 2019 di 15 (lima belas) kecamatan. Masyarakat pendatang yang tinggal di Kota Makassar memiliki kesempatan ikut serta untuk memilih Calon Presiden dan Calon Wakil Presiden, namun harus memenuhi persyaratan sebagai Daftar Pemilih Tambahan (DPTb). Dikutip dari Harian Nasional pada Kamis. 11 April 2019, 
Tabel 1 Rekapitulasi Daftar Pemilih pada Pelaksanaan Pilpres 2019 di Kota Makassar

\begin{tabular}{|c|c|c|c|c|}
\hline \multirow[b]{2}{*}{ No } & \multirow[b]{2}{*}{ Keterangan } & \multicolumn{3}{|c|}{ Jumlah } \\
\hline & & Data Pemilih & $\begin{array}{c}\text { Partisipasi } \\
\text { Pemilih }\end{array}$ & Tidak Memilih \\
\hline \multirow[t]{2}{*}{1} & Daftar Pemilih Tetap (DPT) & 967.590 orang & 649.019 orang & 318.571 orang \\
\hline & & $100 \%$ & $67,12 \%$ & $32,88 \%$ \\
\hline \multirow[t]{2}{*}{2} & Daftar Pemilih Tambahan (DPTb) & 7.267 orang & 6.106 orang & 1.161 orang \\
\hline & & $100 \%$ & $84,02 \%$ & $15,98 \%$ \\
\hline \multirow[t]{4}{*}{3} & Daftar Pemilih Khusus (DPK) & 75.279 orang & 75.279 orang & - \\
\hline & & $100 \%$ & $100 \%$ & \\
\hline & Total & 1.050 .136 orang & 730.404 orang & 317.410 orang \\
\hline & & $100 \%$ & $69,5 \%$ & $30,5 \%$ \\
\hline
\end{tabular}

Sumber: KPU Kota Makassar

total DPTb Nasional sebanyak 800.219 orang tersebar dalam 169.668 TPS se-Indonesia. Sedangkan, di Kota Makassar, rekapitulasi DPTb dapat dilihat pada tabel 1 di atas.

Berdasarkan fakta di lapangan, terdapat beberapa kendala pada saat pelaksanaan Pilpres 2019 di Kota Makassar yang berkaitan dengan kinerja KPU sehingga DPTb pada saat Pilpres tidak mencapai 100\%. Seperti dilansir CNN Indonesia pada pada Rabu, 17 April 2019, "Beberapa TPS di Kota Makassar kehabisan surat suara untuk Daftar Pemilih Tambahan (DPTb) dan Daftar Pemilih Khusus (DPK). Kekurangan tersebut salah satunya terjadi di TPS 74 Perumahan Pemda Kelurahan Manggala, Kota Makassar. Bahkan hampir semua rumah sakit di Makassar, termasuk RSKD Dadi yang menangani orang dengan gangguan jiwa juga tidak melaksanakan pemungutan suara. Menjelang siang, sebanyak 435 orang di Lembaga Pemasyarakatan (Lapas) Kelas IA Makassar juga sempat tertunda melakukan pencoblosan. Mereka merupakan DPTb yang terlambat dilaporkan oleh pihak Lapas sehingga tidak terakomodir dengan baik". Pada dasarnya, kebutuhan akan surat suara didasarkan pada DPTb yang telah terdaftar sebelum pelaksanaan, sehingga hal di atas tidak akan terjadi. Bahkan, apabila terdapat
DPTb yang tidak hadir, seharusnya terdapat lebih pada kertas suara yang disediakan di TPS.

Selain hal yang disebut di atas, masalah yang dihadapi adalah masyarakat pendatang yang sudah terdaftar menjadi DPTb tersebut tidak hadir untuk menggunakan hak pilihnya karena faktor geografis Kota Makassar. Berdasarkan luas kota Makassar, terbentuk 3.959 TPS yang tersebar di 15 Kecamatan dan 153 Kelurahan. Hal ini membuat para masyarakat pendatang kesulitan dalam mencari lokasi TPS yang telah ditentukan untuk menggunakan hak suaranya. Sedangkan dari pihak KPU sendiri belum mempunyai inisiatif untuk mempermudah masyarakat pendatang untuk mencari lokasi misalnya dengan membuat denah yang dipublikasikan di media cetak dan media elektronik.

Pembentukan elemen yang menyangkut pelaksanaan Pilpres menunjukkan bahwa posisi KPU melekat selama proses penyelenggaraan Pilpres, baik pada pra maupun pasca pelaksanaan Pilpres. Sehingga dapat disimpulkan bahwa sukses tidaknya pelaksanaan Piplres tergantung pada kinerja KPU daerah setempat dalam rangka menjunjung tinggi demokrasi dan kedaulatan di tangan rakyat. Pembentukan 
perangkat kerja yang disebut dengan Badan Penyelenggara/ad hoc yang terdiri dari Panitia Pemilih Kecamatan (PPK), Panitia Pemungutan Suara (PPS) dan Kelompok Penyelenggara Pemungutan Suara (KPPS) di Kota Makassar dibentuk melalui seleksi yang diadakan oleh KPU Kota Makassar dengan batas perekrutan tiga orang per kelurahan, namun apabila melebihi akan disesuaikan lagi dengan domisili kelurahan KTP yang bersangkutan.

Di Kota Makassar, masyarakat yang bergabung menjadi Badan Penyelenggara/ ad hoc ini adalah mahasiswa, pemuda karang taruna, rumah tangga, dan masyarakat yang tidak memiliki aktivitas tetap dalam pekerjaannya. Berdasarkan besaran honor yang diterima, dinilai tidak sebanding dengan beban kerja yang berat selama proses awal pemilu hingga selesai perhitungan suara. Faktor honor inilah yang bisa menjadi salah satu penyebab mengapa mereka kurang maksimal dalam melaksanakan sosialisasi dan lebih berfokus pada saat hari pelaksanaan Pilpres.

Kendala lain yang muncul yakni KPU Kota Makassar telah menyampaikan kepada Badan Penyelenggara/Ad hoc tentang administrasi yang harus dilengkapi masyarakat pendatang jika ingin menjadi DPTb, yaitu harus mengisi terlebih dahulu data pribadi pada formulir A5 atau formulir pindah memilih yang didapat dari KPU di tempat yang bersangkutan ingin memilih dengan menunjukkan $e$-KTP. Namun, masih ada masyarakat yang bisa memilih hanya dengan menunjukkan $e$-KTP saja, sehingga ada beberapa TPS di 3 kecamatan (Mariso, Rappocini, dan Manggala) yang harus melakukan pemilihan ulang. Hal ini dilansir Kompas.com pada Sabtu tanggal 20 April 2019, "Punya KTP elektronik, padahal bukan domisili sesuai TPS datang memilih, padahal itu tidak masuk kategori dia. Karena hoaks (yang beredar) itu jadi bisa," Dari kejadian ini dapat disimpulkan bahwa meskipun telah dilaksanakan Bimtek kepada KPPS, namun masih didapati di antara mereka yang kurang profesional dalam menanggapi informasi/percaya akan hoaks utamanya untuk kelengkapan administrasi masyarakat pendatang agar bisa memilih.

Sosialisasi sangat penting dilaksanakan oleh KPU Kota Makassar dalam rangka penyampaian informasi, khususnya kepada masyarakat pendatang yang berada di seluruh wilayah dalam cakupan teritorial Kota Makassar dan ke seluruh elemen masyarakat. Namun, KPU Kota Makassar hanya fokus melaksanakan sosialisasi pada lokasi-lokasi yang mudah dijangkau seperti Kampus, Instansi Pemerintah dan Swasta, sedangkan ada beberapa lokasi yang sangat perlu diadakan sosialisasi di antaranya masyarakat yang tinggal di wilayah sekitar pasar, pelabuhan dan perkampungan. Hal ini menjadi satu masalah baru, yakni tidak semua masyarakat pendatang mendapatkan informasi yang seharusnya mereka dapatkan untuk menggunakan hak suaranya memilih Capres dan Cawapres, sehingga ada masyarakat pendatang yang ingin memilih tetapi tidak tahu prosedurnya.

Pemerintah Kota Makassar memiliki pekerjaan khusus dalam masalah yang terkait dengan sumber daya manusia secara tepat melalui KPU. KPU Kota Makassar sebagai Lembaga Penyelenggara Pilpres di Kota Makassar yang mempunyai peranan penting dalam meningkatkan partisipasi masyarakat, khususnya masyarakat pendatang. KPU diharapkan dapat menegakkan peraturan pemilihan umum secara konsisten sesuai dengan peraturan Perundang-undangan yang berlaku. Untuk menahan dan menekan partisipasi masyarakat pendatang yang rendah, KPU berupaya dengan meningkatkan kesadaran masyarakat pendatang untuk berpartisipasi aktif dalam pemilihan umum demi terwujudnya cita-cita masyarakat Indonesia yang demokratis. 


\section{Identifikasi Masalah}

Memperhatikan uraian-uraian di atas, dapat diidentifikasi berbagai permasalahan yang terjadi sebagai berikut.

1. Seharusnya jumlah surat suara untuk masyarakat pendatang yang ada di TPS sesuai dengan DPTb yang terdaftar, namun pada beberapa TPS terjadi kekurangan surat suara terutama DPTb yang berada hampir di seluruh Rumah Sakit Makassar dan Lapas.

2. KPU Kota Makassar seharusnya memberikan info secara jelas mengenai lokasi TPS, namun masih terdapat DPTb yang kesulitan dalam mencari lokasi TPS di mana dia harus memilih.

3. Besaran honor seharusnya sesuai dengan beban kerjanya, namun terdapat ketidakseimbangan antara honor yang diterima petugas di lapangan dengan beban kerja yang berat dari pra dan pasca Pemilu.

4. KPPS telah mendapatkan pembekalan sebelum penyelenggaraan Pilpres, namun masih ada yang belum profesional dan percaya hoaks mengenai kelengkapan administrasi masyarakat pendatang untuk menjadi DPTb.

5. Sosialisasi seharusnya dilaksanakan oleh KPU ke seluruh elemen masyarakat, tetapi yang terjadi adalah sosialisasi hanya dilaksanakan di beberapa tempat seperti Kampus, Instansi Pemerintah dan Swasta.

6. Sebagai Warga Negara seharusnya ikut serta menyukseskan pesta demokrasi, namun terdapat masyarakat pendatang yang tahu prosedur menjadi DPTb namun tidak mau.

\section{Pembatasan dan Perumusan Masalah}

Berdasarkan uraian di atas, maka permasalahan yang akan diteliti dibatasi pada kinerja KPU Kota Makassar dalam Meningkatkan partisipasi masyarakat pendatang pada Pilpres 2019.

Mengacu pada pembatasan masalah di atas, rumusan masalah yang akan diteliti adalah:

1. Bagaimana kinerja KPU Kota Makassar dalam Meningkatkan partisipasi masyarakat pendatang pada Pilpres 2019 ?

2. Faktor-faktor apa yang memengaruhi kinerja KPU Kota Makassar dalam Meningkatkan partisipasi masyarakat pendatang pada Pilpres 2019?

3. Bagaimana upaya KPU Kota Makassar dalam mengatasi hambatan untuk meningkatkan partisipasi masyarakat pendatang pada Pilpres 2019?

\section{Maksud dan Tujuan Penelitian}

Penelitian ini bermaksud untuk memperoleh dan mengkaji data dan informasi tentang kinerja KPU Kota Makassar dalam Meningkatkan partisipasi masyarakat pendatang pada Pilpres 2019.

Adapun tujuan yang ingin dicapai dari penelitian ini adalah sebagai berikut.

1. Untuk mengetahui dan menganalisis kinerja KPU Kota Makassar dalam Meningkatkan partisipasi masyarakat pendatang pada Pilpres 2019.

2. Untuk mengetahui dan menganalisis faktor-faktor apa yang memengaruhi kinerja KPU Kota Makassar dalam Meningkatkan partisipasi masyarakat pendatang pada Pilpres 2019.

3. Untuk mengetahui dan menganalisis upaya KPU Kota Makassar dalam mengatasi hambatan untuk meningkatkan partisipasi masyarakat pendatang pada Pilpres 2019.

\section{Kegunaan Penelitian}

Hasil penelitian ini secara teoretis dapat dijadikan bahan kajian bagi pengembangan konsep bagaimana mewujudkan KPU yang mampu menunjukkan kinerjanya 
kepada masyarakat, khususnya masyarakat pendatang dalam meningkatkan partisipasi masyarakat pendatang pada Pilpres dan sebagai pembanding teori-teori yang didapat selama pendidikan dengan kenyataan yang ada di lapangan.

Adapun kegunaan praktis hasil penelitian ini adalah sebagai berikut.

1. Bagi penulis, penelitian ini diharapkan dapat memberikan tambahan pengetahuan dan pengalaman dari pelaksanaan tugas di lapangan.

2. Bagi KPU Kota Makassar Provinsi Sulawesi Selatan, sebagai masukan agar ke depannya bekerja secara optimal, khususnya dalam meningkatkan partisipasi masyarakat pendatang pada Pilpres periode selanjutnya.

3. Bagi Pascasarjana IPDN, penelitian ini diharapkan dapat menjadi bahan kajian dan rujukan bagi penelitian selanjutnya yang membahas tentang kinerja KPU dalam meningkatkan partisipasi masyarakat pendatang pada Pilpres.

\section{KAJIAN PUSTAKA}

\section{Kajian Terdahulu}

Sebagai bahan perbandingan dalam penelitian ini akan dicantumkan beberapa penelitian terdahulu yang telah dilakukan oleh peneliti lain, sebagaimana tampak pada tabel 2 .

\section{Manajemen}

Manajemen secara etimologi berasal dari bahasa Inggris, yaitu management yang berasal dari kata kerja to manage berarti kontrol. Dalam bahasa Indonesia, manajemen dapat diartikan mengendalikan, menangani, atau mengelola. Menurut Ndraha dalam bukunya Kybernology (Ilmu Pemerintahan Baru) I disebutkan bahwa istilah manajemen datang dari bahasa Inggris management. Istilah ini terbentuk dari akar kata manusia, tangan, yang berkaitan dengan kata menagarie yang berarti berternak. Menagarie juga berarti sekumpulan binatang liar yang dikendalikan di dalam pagar. Kata manusia berkaitan dengan kata manage yang berasal dari bahasa Latin mansionaticum yang berarti pengelolaan rumah besar. Manajemen mempelajari bagaimana menciptakan efektivitas usaha (doing right things) secara efisien (doing things right) dan produktif, melalui fungsi dan siklus tertentu, dalam rangka mencapai tujuan organisasional yang telah ditetapkan (Ndraha, 2011: 159).

\section{Pemerintahan}

Sebagai makhluk sosial, manusia membutuhkan manusia lain untuk bekerja sama dalam memenuhi segala kebutuhan hidupnya, termasuk keamanan, kenyamanan, keselamatan, dan kesejahteraan. Dalam bekerja sama inilah manusia membutuhkan suatu wadah tertentu tempat manusia bekerja sama. Manusia bersatu dalam suatu tatanan bermasyarakat yang biasa dikenal dengan istilah "Negara".

Berkaitan dengan hal tersebut dalam menjalankan Negara, Salam (2007:34) mengemukakan:

Untuk menjalankan sebuah negara agar dapat mencapai ketenteraman, kesejahteraan, dan kesentosaan bersama diperlukan penguasa yang mengatur dan mengelola segenap sumber daya untuk mencapai tujuan suatu negara. Penguasa dalam terminologi ilmu negara, ilmu politik, ilmu administrasi biasanya dengan istilah pemerintah. Sedangkan kegiatan pemerintah dalam menjalankan kekuasaan negara disebut dengan istilah pemerintahan.

\section{Manajemen Pemerintahan}

Dari penjelasan mengenai pengertian manajemen dan pemerintahan, kemudian dikenal istilah manajemen pemerintahan. 
Tabel 2 Persamaan dan Perbedaan dengan Penelitian Dahulu

\begin{tabular}{|c|c|c|c|c|}
\hline No & $\begin{array}{c}\text { Nama Peneliti } \\
\text { Terdahulu }\end{array}$ & Judul Penelitian & Persamaan Penelitian & Perbedaan Penelitian \\
\hline 1. & $\begin{array}{l}\text { Willians } \\
\text { Timpal }\end{array}$ & $\begin{array}{lr}\text { Peran } & \text { Komisi } \\
\text { Pemilihan } & \text { Umum } \\
\text { dalam } & \text { Menangani } \\
\text { Pemilih } & \text { Khusus } \\
\text { Tambahan } & \text { pada } \\
\text { Pemilihan } & \text { Umum } \\
\text { Presiden dan } & \text { Wakil } \\
\text { Presiden Tahun } & 2014 \\
\text { di Kota Tomohon }\end{array}$ & $\begin{array}{l}\text { a. Instansi yang } \\
\text { diteliti } \\
\text { b. Metode penelitian } \\
\text { Kualitatif } \\
\text { c. Objek Penelitian } \\
\text { Pemilih Tambahan } \\
\text { d. Kegiatan yang } \\
\text { dikaji Pilpres }\end{array}$ & $\begin{array}{l}\text { a. Teori yang } \\
\text { digunakan } \\
\text { b. Lokasi penelitian } \\
\text { c. Masalah utama } \\
\text { d. Tahun Pelaksanaan } \\
\text { Pilpres }\end{array}$ \\
\hline 2. & E. Anusapati & $\begin{array}{lr}\text { Kinerja } & \text { Aparatur } \\
\text { Komisi } & \text { Pemilihan } \\
\text { Umum } & \text { Kabupaten } \\
\text { Kubu Raya } & \end{array}$ & $\begin{array}{l}\text { a. Instansi yang } \\
\text { diteliti } \\
\text { b. Metode penelitian } \\
\text { Kualitatif }\end{array}$ & $\begin{array}{l}\text { a. Lokasi penelitian } \\
\text { b. Objek penelitian } \\
\text { khusus Aparatur } \\
\text { KPU } \\
\text { c. Tahun Pelaksanaan }\end{array}$ \\
\hline 3. & Tohap Hasugian & $\begin{array}{lr}\text { Strategi } & \text { Komisi } \\
\text { Pemilihan } & \text { Umum } \\
\text { dalam } & \text { Meningkatkan } \\
\text { Partisipasi } & \text { Pemilih } \\
\text { (Studi Pemilih Pemula, } \\
\text { Perempuan } & \text { dan } \\
\text { Kelompok } & \text { Marjinal } \\
\text { pada Pemilihan Bupati } \\
\text { dan Wakil Bupati 2018 } \\
\text { di Kabupaten Dairi } \\
\begin{array}{l}\text { Provinsi } \\
\text { Utara) Sumatera }\end{array}\end{array}$ & $\begin{array}{lr}\text { a. Instansi yang } \\
\text { diteliti } \\
\text { b. Metode penelitian } \\
\text { kualitatif } \\
\text { c. Tujuan yang } \\
\text { diukur, yaitu } \\
\text { tingkat partisipasi } \\
\text { pemilih r }\end{array}$ & $\begin{array}{l}\text { a. Teori yang } \\
\text { digunakan } \\
\text { b. Lokasi penelitian } \\
\text { c. Masalah utama } \\
\text { d. Kegiatan yang } \\
\text { dikaji, yaitu pemilu } \\
\text { e. Objek penelitian } \\
\text { f. Tahun pelaksanaan } \\
\text { pemilu }\end{array}$ \\
\hline
\end{tabular}

Istianto (2011: 29) dalam bukunya Manajemen Pemerintahan dalam Perspektif Pelayanan Publik mengatakan bahwa:

Manajemen pemerintahan diartikan pada bagaimana secara organisasional untuk mengimplementasikan kebijakan publik. Dengan demikian manajemen pemerintahan lebih terfokus pada alat-alat manajerial, teknis pengetahuan dan keterampilan yang dapat digunakan untuk mengubah ide-ide dan kebijakan menjadi program tindakan.

Penyelenggaraan pemerintahan Indonesia di dalam kerangka negara kesatuan, antara pemerintah pusat dan pemerintah daerah di dalam pelaksanaannya tidak dapat dilepaskan dari penggunaan asas penyelenggaraan pemerintahan di daerah. UU No. 23 Tahun 2014 tentang Pemerintahan Daerah yang pada prinsipnya mengatur penyelenggaraan pemerintahan daerah yang lebih mengutamakan pelaksanaan asas desentralisasi.

Konsep dasar dari manajemen pemerintahan tidak lain adalah manajemen itu sendiri. Manajemen pada intinya menurut Ndraha (2011: 159) adalah "bagaimana menciptakan effectiveness usaha ("doing right things") secara efficient ("doing things 
right") dan produktif, melalui fungsi dan skill tertentu, dalam rangka mencapai tujuan organisasional yang telah ditetapkan."

\section{Kinerja}

Menurut Mahmudi (2010:20) menyatakan bahwa kinerja merupakan:

Organisasi pada dasarnya merupakan tanggung jawab setiap individu yang bekerja dalam organisasi. Tanggung jawab terhadap manajemen kinerja sebenarnya tidak lahir dari manajer tetapi dari individu. Apabila dalam organisasi setiap individu bekerja dengan baik, berprestasi dan bersemangat, dan memberikan kontribusi terbaik mereka terhadap organisasi, maka kinerja organisasi secara keseluruhan akan baik. Dengan demikian, kinerja organisasi merupakan cerminan dari kinerja individu.

Untuk mengukur kinerja, dimensidimensi kinerja dikembangkan menjadi indikator kinerja. Indikator kinerja digunakan untuk mengembangkan instrumen evaluasi kinerja yang kemudian digunakan untuk mengukur kinerja seorang pegawai.

Teori kinerja dari Agus Dwiyanto dalam buku Reformasi Birokrasi Publik di Indonesia (2008:50-51) terdapat beberapa indikator untuk mengukur kinerja birokrasi publik (Dwiyanto, 1995), yaitu sebagai berikut.

\section{Produktivitas}

Konsep produktivitas tidak hanya mengukur tingkat efisiensi, tetapi juga efektivitas pelayanan. Produktivitas pada umumnya dipahami sebagai rasio antara input dengan output. Konsep produktivitas dirasa terlalu sempit dan kemudian General Accounting Office (GAO) mencoba mengembangkan satu ukuran produktivitas yang lebih luas dengan memasukkan seberapa besar pelayanan publik itu memiliki hasil yang diharapkan sebagai salah satu indikator kinerja yang penting.

\section{Kualitas layanan}

Isu mengenai kualitas layanan cenderung menjadi semakin penting dalam menjelaskan kinerja organisasi pelayanan publik. Banyak pandangan negatif yang terbentuk mengenai organisasi publik muncul karena ketidakpuasan masyarakat terhadap kualitas layanan yang diterima dari organisasi publik. Dengan demikian, kepuasan masyarakat terhadap layanan dapat dijadikan indikator kinerja organisasi publik. Keuntungan utama menggunakan kepuasan masyarakat sebagai indikator kinerja adalah informasi mengenai kepuasan masyarakat sering kali tersedia secara mudah dan murah. Informasi mengenai kepuasan terhadap kualitas pelayanan sering kali dapat diperoleh dari media massa atau diskusi publik. Akibat akses terhadap informasi mengenai kepuasan masyarakat terhadap kualitas layanan relatif sangat tinggi, maka bisa menjadi satu ukuran kinerja organisasi publik yang mudah dan murah dipergunakan. Kepuasan masyarakat bisa menjadi parameter untuk menilai kinerja organisasi publik.

3. Responsivitas

Responsivitas adalah kemampuan organisasi untuk mengenali kebutuhan masyarakat, menyusun agenda dan prioritas pelayanan, dan mengembangkan program-program pelayanan publik sesuai dengan kebutuhan dan aspirasi masyarakat. Secara singkat responsivitas di sini menunjuk pada keselarasan antara program dan kegiatan pelayanan dengan kebutuhan dan aspirasi masyarakat. Responsivitas dimasukkan sebagai salah satu indikator kinerja karena responsivitas secara langsung menggambarkan kemampuan organisasi publik dalam menjalankan misi dan 
tujuannya, terutama untuk memenuhi kebutuhan masyarakat. Responsivitas yang rendah ditunjukkan dengan ketidakselarasan antara pelayanan dengan kebutuhan masyarakat. Hal tersebut jelas menunjukkan kegagalan organisasi dalam mewujudkan misi dan tujuan organisasi publik. Organisasi yang memiliki responsivitas rendah dengan sendirinya memiliki kinerja yang jelek pula.

4. Responsibilitas

Responsibilitas menjelaskan apakah pelaksanaan kegiatan organisasi publik itu dilakukan sesuai dengan prinsipprinsip administrasi yang benar atau sesuai dengan kebijakan organisasi, baik yang eksplisit maupun implisit (Lenvine, 1990). Oleh sebab itu, responsibilitas bisa saja pada suatu ketika berbenturan dengan responsivitas.

5. Akuntabilitas

Akuntabilitas publik menunjuk pada seberapa besar kebijakan dan kegiatan organisasi publik tunduk pada para pejabat politik yang dipilih oleh rakyat. Asumsinya adalah bahwa para pejabat politik tersebut karena dipilih oleh rakyat, dengan sendirinya akan selalu merepresentasikan kepentingan rakyat. Dalam konteks ini, konsep akuntabilitas publik dapat digunakan untuk melihat seberapa besar kebijakan dan kegiatan organisasi publik itu konsisten dengan kehendak masyarakat banyak. Kinerja organisasi publik tidak bisa dilihat dari ukuran internal yang dikembangkan oleh organisasi publik atau pemerintah, seperti pencapaian target. Kinerja sebaiknya harus dinilai dari ukuran eksternal, seperti nilai-nilai dan norma yang berlaku dalam masyarakat. Suatu kegiatan organisasi publik memiliki akuntabilitas yang tinggi kalau kegiatan itu dianggap benar dan sesuai dengan nilai dan norma yang berkembang dalam masyarakat.
Dari beberapa pendapat di atas, penulis memilih untuk menggunakan indikator pengukuran kinerja yang dikemukakan oleh Agus Dwiyanto (2008:50-51). Penulis memilih menggunakan teori tentang pengukuran kinerja yang dikemukakan oleh Agus Dwiyanto (2008:50-51) tersebut karena dipandang sesuai, lebih tepat dan lebih mampu mengukur kinerja KPU Kota Makassar dalam Meningkatkan partisipasi masyarakat pendatang pada Pilpres 2019.

\section{Komisi Pemilihan Umum}

Komisi Pemilihan Umum (KPU) adalah lembaga Negara yang menyelenggarakan pemilihan umum di Indonesia, yakin meliputi Pemilihan Umum Anggota DPR, DPD, DPRD, Pemilihan Umum Presiden dan Wakil Presiden, serta Pemilihan Umum Kepala Daerah dan Wakil Kepala Daerah. Sebelum Pemilu 2004, KPU dapat terdiri dari anggotaanggota yang merupakan anggota sebuah partai politik, namun setelah dikeluarkannya Undang-Undang Nomor 4 Tahun 2000 pada tahun 2000, maka diharuskan bahwa KPU adalah non-partisan.

Dalam Undang-Undang Nomor 7 Tahun 2017 tentang Pemilihan Umum, Komisi Pemilihan Umum yang selanjutnya disingkat KPU adalah lembaga Penyelenggara Pemilu yang bersifat nasional, tetap, dan mandiri dalam melaksanakan Pemilu.

\section{Partisipasi Masyarakat Pendatang}

Menurut Mikkelsen dalam Adi (2008:107), "Partisipasi adalah keterlibatan masyarakat dalam upaya pembangunan lingkungan, dan dirimereka sendiri.Selainitu, partisipasi adalah keterlibatan masyarakat secara sukarela dalam perubahan yang ditentukan sendiri oleh masyarakat."

Partisipasi masyarakat menurut Adi (2008:27) adalah "keikutsertaan masyarakat dalam proses pengidentifikasian masalah dan potensi yang ada di masyarakat, pemilihan dan pengambilan keputusan 
tentang alternatif solusi untuk menangani masalah, pelaksanaan upaya mengatasi masalah, dan keterlibatan masyarakat dalam proses mengevaluasi perubahan yang terjadi."

Dari penjelasan di atas dapat disimpulkan bahwa partisipasi masyarakat pendatang adalah keikutsertaan masyarakat pendatang dalam pemilihan, pelaksanaan dan menangani masalah, serta keterlibatan dalam mengevaluasi konflik yang terjadi.

\section{Demokrasi}

Demokrasi adalah bentuk pemerintahan yang semua warga negaranya memiliki hak setara dalam pengambilan keputusan yang dapat mengubah hidup mereka. Demokrasi mengizinkan warga negara berpartisipasi baik secara langsung atau melalui perwakilan dalam perumusan, pengembangan, dan pembuatan hukum. Demokrasi mencakup kondisi sosial, ekonomi, dan budaya yang memungkinkan adanya praktik kebebasan politik secara bebas dan setara.

Ada beberapa jenis demokrasi, tetapi hanya ada dua bentuk dasar. Keduanya menjelaskan cara seluruh rakyat menjalankan keinginannya. Bentuk demokrasi yang pertama adalah demokrasi langsung, yaitu semua warga negara berpartisipasi langsung dan aktif dalam pengambilan keputusan pemerintahan. Di kebanyakan negara demokrasi modern, seluruh rakyat masih merupakan satu kekuasaan berdaulat namun kekuasaan politiknya dijalankan secara tidak langsung melalui perwakilan; ini disebut demokrasi perwakilan. Konsep demokrasi perwakilan muncul dari ide-ide dan institusi yang berkembang pada Abad Pertengahan Eropa, Era Pencerahan, dan Revolusi Amerika Serikat dan Perancis.

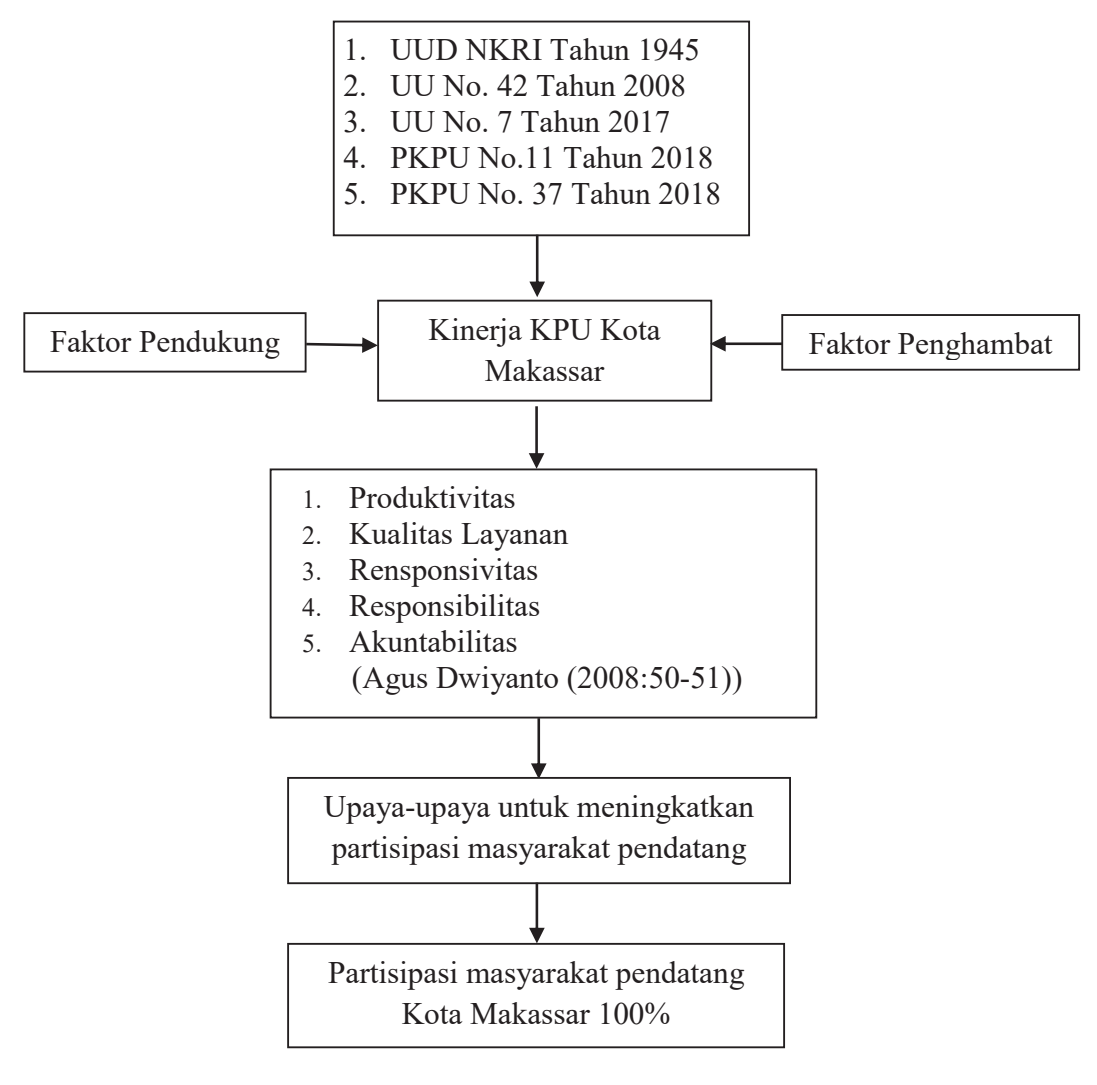

Gambar 1

Kerangka Pemikiran 


\section{Pemilihan Presiden dan Wakil Presiden}

Pemilihan Presiden dan Wakil Presiden (Pilpres) dilakukan secara langsung oleh masyarakat setempat yang memenuhi syarat. Pilpres dilakukan satu paket bersama dengan Wakil Presiden. Pemilihan umum presiden dan wakil presiden adalah sarana pelaksanaan kedaulatan rakyat dalam Negara Kesatuan Republik Indonesia yang berdasarkan Pancasila dan UUD 1945 untuk memilih presiden dan wakil presiden. Pilpres dilaksanakan berdasarkan asas langsung, umum, bebas, rahasia, jujur, dan adil. Pilpres dilaksanakan setiap 5 tahun sekali pada libur dan hari yang diliburkan, dan pemilihan ini satu rangkaian dengan pemilu anggota DPR, DPD, dan DPRD.

\section{KERANGKA PEMIKIRAN}

Menurut Sugiyono

(2013:60) mengemukakan bahwa kerangka berpikir merupakan model konseptual tentang bagaimana teori berhubungan dengan berbagai faktor yang telah diidentifikasi sebagai masalah yang penting. Kerangka pemikiran penelitian ini sebagaimana tampak pada gambar 1 di muka.

\section{METODE PENELITIAN}

\section{Desain Penelitian}

Desain penelitian dimulai dari
penyusunan kerangka konseptual,
identifikasi masalah, perumusan hipotesis,
pengumpulan data sampai pada dengan
proses analisis data yang sangat berguna
sebagai pedoman peneliti dalam mencapai
tujuan penelitian terkait dengan teori dan
kepustakaan yang ada.

Menurut Moleong (2012:6) menyatakan bahwa "penelitian kualitatif penelitian yang bermaksud untuk memahami fenomena tentang apa yang dialami oleh subjek penelitian, misalnya perilaku, persepsi, tindakan dan lain-lain."

Penulis menggunakan metode deskriptif, yaitu berusaha mencari pemahaman makna berdasarkan fakta atau kenyataan yang ada di lokasi penelitian, kemudian dilakukan penelaahan agar diperoleh gambaran yang jelas dan sistematis dalam rangka pemecahan masalah yang dihadapi. Peneliti melakukannya dengan cara melukiskan, memaparkan dan menyusun hasil suatu keadaan secara teratur sesuai dengan fakta yang berhubungan serta berpengaruh dari suatu fenomena yang dihubungkan dengan teori yang ada agar dapat menarik simpulan dalam upaya pemecahan masalah. Tujuan dari penelitian ini adalah untuk membuat deskripsi, gambaran atau lukisan secara sistematis, faktual dan akurat mengenai fakta-fakta, sifat-sifat serta hubungan antarfenomena yang diteliti.

Penelitian ini bertujuan untuk mengetahui dan menganalisis bagaimana kinerja KPU Kota Makassar dalam Meningkatkan partisipasi masyarakat pendatang pada Pilpres 2019 dan untuk mengetahui dan menganalisis faktor-faktor apa yang menghambat kinerja KPU Kota Makassar dalam Meningkatkan partisipasi masyarakat pendatang pada Pilpres 2019. Dengan demikian maka penelitian ini mendeskripsikan kondisi geografis dan demografis terutama jumlah penduduk, pendidikan, sosial ekonomi, sarana dan prasarana, instansi penelitian, dan indikator kinerja, sehingga dapat diketahui peningkatan partisipasi masyarakat pendatangnya.

\section{Sumber Data}

Menurut Arikunto (2010:172) memiliki pendapat tentang sumber data bahwa:

Sumber data adalah subjek dari mana data dapat diperoleh. Apabila penulis menggunakan kuisioner atau wawancara dalam pengumpulan datadatanya, maka sumber data tersebut 
disebut responden. Apabila penulis menggunakan teknik observasi, maka sumber-sumber datanya dapat berupa benda, gerak atau proses sesuatu, dan apabila penulis menggunakan dokumentasi, maka dokumen atau catatanlah yang menjadi sumber data.

\section{Informan/Responden dan Cara Menentukannya}

Sehubungan dengan penelitian ini menggunakan metode penelitian deskriptif kualitatif, maka penulis tidak menggunakan populasi dan sampel. Menurut Arikunto (2010:13) menyatakan bahwa "Penelitian kualitatif tidak menggunakan pendekatan populasi dan sampel. Dengan kata lain, dalam penelitian kualitatif tidak dikenal istilah populasi dan sampel. Istilah yang digunakan adalah setting." Hasil penelitian hanya berlaku bagi setting yang bersangkutan.

Hal ini juga sejalan dengan pendapat Sugiyono (2013:50) bahwa:

Dalam penelitian kualitatif tidak menggunakan populasi, karena penelitian kualitatif berangkat dari kasus tertentu yang ada pada situasi sosial tertentu dan hasil kajiannya tidak akan diberlakukan ke populasi, tetapi ditransferkan ke tempat lain pada situasi sosial yang memiliki kesamaan dengan situasi sosial pada kasus yang dipelajari.

Oleh karena itu, dalam metode penelitian deskriptif kualitatif ini, penulis hanya menggunakan informan saja. Sedangkan Sugiyono (2013:50) menyatakan bahwa "Sampel dalam penelitian kualitatif bukan dinamakan sumber data, tetapi narasumber, atau partisipan, informan, teman dan guru dalam penelitian." Sampel dalam penelitian kualitatif, juga bukan disebut sampel statistik, tetapi sampel teoretis, karena tujuan penelitian kualitatif adalah menghasilkan teori.
Berdasarkan definisi informan di atas maka penulis menetapkan bahwa yang menjadi informan dalam penelitian ini sebagai berikut

Tabel 3 Daftar Informan

\begin{tabular}{|c|c|c|c|}
\hline No & $\begin{array}{l}\text { Sumber } \\
\text { informan }\end{array}$ & Jumlah & Keterangan \\
\hline 1 & $\begin{array}{l}\text { Policy } \\
\text { Maker }\end{array}$ & 1 orang & $\begin{array}{l}\text { Ketua KPU Kota } \\
\text { Makassar }\end{array}$ \\
\hline 2 & $\begin{array}{l}\text { Imple- } \\
\text { mentor }\end{array}$ & $\begin{array}{l}1 \text { orang } \\
4 \text { orang } \\
4 \text { orang }\end{array}$ & $\begin{array}{l}\text { - Sekretaris KPU } \\
\text { Kota Makassar } \\
\text { - } \text { Divisi KPU Kota } \\
\text { Makassar } \\
\text { - Kepala Sub } \\
\text { Bagian } \\
\text { Sekretariat } \\
\text { KPU Kota } \\
\text { Makassar }\end{array}$ \\
\hline 3 & $\begin{array}{l}\text { Target } \\
\text { Grup }\end{array}$ & $\begin{array}{l}2 \text { orang } \\
2 \text { orang } \\
2 \text { orang } \\
5 \text { orang }\end{array}$ & $\begin{array}{l}\text { PPK (Panitia } \\
\text { Pemilihan } \\
\text { Kecamatan) } \\
\text { - } \quad \text { PPS (Panitia } \\
\text { Pemungutan } \\
\text { Suara) } \\
\text { - KPPS } \\
\text { (Kelompok } \\
\text { Penyelenggara } \\
\text { Pemungutan } \\
\text { Suara) } \\
\text { DPTb (Daftar } \\
\text { Pemilih } \\
\text { Tambahan) }\end{array}$ \\
\hline & Jumlah & 21 orang & \\
\hline
\end{tabular}

\section{Teknik Pengumpulan Data}

Menurut Suharsaputra (2012:207) menyatakan bahwa "Pengumpulan data pada dasarnya merupakan serangkaian proses yang dilakukan sesuai dengan metode penelitian yang dipergunakan."

Menurut Sugiyono menyatakan bahwa:

Dalam pengumpulan data, teknik yang dilakukan dengan observasi, wawancara, dokumentasi, dan 
triangulasi (gabungan). Oleh karena itu teknik pengumpulan data, yaitu usaha yang dilakukan untuk mengumpulkan informasi-informasi yang berhubungan erat dengan masalah yang sedang diamati untuk memperoleh data yang diperlukan sehingga data yang diperoleh bersifat valid (menggambarkan yang sebenarnya), reliable (dapat dipercaya), dan objektif (sesuai dengan kenyataan).

Menurut Nasution (2011:113):

Wawancara adalah suatu bentuk komunikasi verbal, jadi semacam percakapan yang bertujuan memperoleh informasi. Wawancara dalam penelitian ini digunakan untuk memperoleh keterangan, informasi atau penjelasan-penjelasan dari Subjek penelitian tentang masalah yang diungkap. Teknik wawancara dimaksudkan untuk mengumpulkan data primer yang dilakukan melalui wawancara secara mendalam (indepth interview) dengan memakai pedoman wawancara (interview guide) sebagai instrumen. Pedoman wawancara sebagai penuntun bagi peneliti dalam mengembangkan pertanyaanpertanyaan yang bersifat terbuka kepada informan yang ditentukan. Informan diberi kebebasan yang seluas-luasnya untuk menyampaikan pendapatnya tentang suatu gejala, fenomena dan situasi.

Suatu wawancara dapat bersifat sebagai suatu proses interaksi dan komunikasi dalam mencari sejumlah variabel yang merupakan peranan yang penting karena akan menentukan hasil yang ingin dicapai. Wawancara dapat dilakukan dengan menggunakan banyak cara, baik dengan cara tatap muka (face to face) maupun dengan menggunakan alat bantu komunikasi serta wawancara ada yang terstruktur maupun tidak terstruktur.
Menurut Arikunto

(2010:274) bahwa teknik pengumpulan data dengan dokumentasi ialah mencari data mengenai hal-hal atau variabel yang berupa catatan, transkrip, buku, surat kabar, majalah, notulen rapat, leger, agenda, dan sebagainya. Peneliti mencari data berupa catatan, buku, surat kabar, dan website terkait kinerja KPU Kota Makassar.

\section{Instrumen Pengumpulan Data}

Menurut Sugiyono (2012:192) bahwa:

Instrumen penelitian adalah alat pada waktu penelitian menggunakan suatu metode. Lebih lanjut dikatakan bahwa peneliti kualitatif sebagai human instrument berfungsi menetapkan fokus penelitian, memilih informan sebagai sumber data, melakukan pengumpulan data, menilai kualitas data, analisis data, menafsirkan data, dan membuat simpulan atas temuannya.

Dalam penelitian ini penulis menggunakan metode wawancara, maka instrumennya adalah pedoman wawancara dengan menggunakan pedoman wawancara sebagai instrumennya maka penulis melakukan wawancara serta pencatatan terhadap data yang diperlukan terkait kinerja KPU Kota Makassar dalam Meningkatkan partisipasi masyarakat pendatang pada Pilpres 2019.

\section{Teknik Analisis Data}

Sugiyono (2013:335) menyatakan analisis data kualitatif adalah bersifat induktif, yaitu suatu analisis berdasarkan data yang diperoleh, selanjutnya dikembangkan pola hubungan tertentu atau menjadi hipotesis. Langkah-langkah yang dilakukan dalam menganalisis data menurut model Miles and Huberman dalam Sugiyono (2013:337), mengemukakan bahwa aktivitas dalam analisis data, yaitu data reduction, data displai, dan data conclusion drawing/ verification. 


\section{Lokasi dan Jadwal Penelitian}

Penelitian dilaksanakan di Kota Makassar Provinsi Sulawesi Selatan, di kantor KPU Kota Makassar.

\section{HASIL DAN PEMBAHASAN}

Berdasarkan KAJIAN PUSTAKA yang telah penulis uraikan yakni menurut Agus Dwiyanto (2008:50-51), melalui teori-teori yang relevan, hasil wawancara penulis dengan narasumber, dan melalui data yang didapat, maka indikator-indikator kinerja KPU Kota Makassar dalam Meningkatkan partisipasi masyarakat pendatang pada Pilpres 2019 adalah Produktivitas, Kualitas Layanan, Responsivitas, Responsibilitas, dan Akuntabilitas.

\section{Produktivitas}

KPU Kota Makassar membutuhkan segala sesuatu yang mendukung pelaksanaan kegiatan Pilpres Kota Makassar Tahun 2019. Indikator ini mengukur Input yang menjadi masukan dan Output yang menjadi hasil/ keluaran dalam kegiatan Pilpres 2019. Dengan melihat proses tersebut, penulis dapat menganalisis apakah hasil yang dicapai sesuai dengan masukan dan keluaran hasil yang ditetapkan.

Hal-hal yang termasuk dalam indikator produktivitas yang menyangkut partisipasi masyarakat pendatang di Kota Makassar pada Pilpres 2019 dijadikan bahan yang nantinya akan diolah KPU Kota Makassar selama pelaksanaan kegiatan. Rencana yang telah ditetapkan untuk melaksanakan Pilpres 2019 dijabarkan dalam bentuk Anggaran, Kuantitas Sumber Daya Manusia, Standar Operasional Prosedur, Rencana Program, serta Sarana dan Prasarana.

Anggaran merupakan suatu rencana kerja yang dituangkan dalam bentuk moneter yang berlaku dalam jangka waktu tertentu. Mekanisme pengusulan anggaran Pilpres 2019, yaitu KPU RI mengusulkan ke DPR RI, sedangkan KPU Kota Makassar menerima anggaran yang telah ditetapkan oleh KPU RI berdasarkan estimasi keperluan dengan mengacu jumlah TPS dan jumlah Pemilih. Dalam pelaksanaan Pilpres 2019 oleh KPU Kota Makassar, anggaran yang dimiliki sekitar Rp 43.800.000.000,00 (Empat Puluh Tiga Milyar Delapan Ratus Juta Rupiah).

Sumber Daya Manusia (SDM) merupakan semua orang yang dipekerjakan (pegawai) dan mengoperasikan sebuah organisasi. Berikut adalah hasil wawancara bersama Romi Harminto, M.Ag selaku Divisi Perencanaan dan Data terkait SDM di KPU Kota Makassar pada saat Pilpres 2019, pada Selasa tanggal 5 Mei 2020 pukul 11.17 WITA melalui media online WhatsApp, Beliau menyatakan bahwa:

Di KPU Kota Makassar, ada Komisioner sejumlah 5 orang. ASN yang di Sekretariat sejumlah 33 orang terdiri dari 1 sekretaris, 4 Kasubbag, selebihnya staf. Jumlah anggota ini masih kurang pada saat pelaksanaan proses Pilpres, karena begitu banyak warga Kota Makassar yang datang ke KPU Kota Makassar minta untuk dilayani dengan cepat.

Sejalan dengan pernyataan tersebut, hasil wawancara bersama Aryastuti Arudji, SE selaku Kasubbag Program dan Data KPU Kota Makassar pada Kamis tanggal 16 April 2020 pukul 11.02 WITA melalui media online WhatsApp, Beliau menyatakan bahwa:

Semua formasi terisi atau terpenuhi dengan jumlah yang ada, namun masih kekurangan jumlah personel dalam pelaksanaan Pilpres, karena begitu banyak masyarakat yang datang.

\section{Standar Operasional Prosedur (SOP)} adalah prosedur yang dilakukan secara kronologis untuk menyelesaikan suatu pekerjaan yang bertujuan memperoleh hasil maksimal. KPU Kota Makassar dalam menjalankan tugas pada Pilpres 2019 berdasarkan SOP yang telah ditetapkan oleh KPU pusat. SOP tersebut yang dijadikan dasar 
dalam melayani masyarakat pendatang yang ingin pindah memilih.

Rencana Program merupakan rangkaian kegiatan-kegiatan untuk mencapai tujuan. KPU Kota Makassar dalam melaksanakan rencana program juga berpedoman pada PKPU dari pusat yang sudah diatur. Rencana program tersebut sesuai dengan PKPU Nomor 14 Tahun 2019 tentang Perubahan Kelima Atas Perubahan Komisi Pemilihan Umum Nomor 7 Tahun 2017 tentang Tahapan, Program, dan Jadwal Penyelenggaraan Pemilihan Umum Tahun 2019.

Sarana dan Prasarana merupakan dua hal yang saling menunjang antara satu dengan yang lain. Adapun sarana adalah alat yang digunakan untuk melancarkan tujuan sedangkan prasarana adalah alat yang menunjang langsung segala jenis fasilitas. Sarana dan prasarana dalam pilpres, yaitu pengadaan alat kelengkapan TPS, serta alat yang mendukung penghitungan suara contohnya scanner dan PC.

\section{Kualitas Layanan}

Salah satu indikator untuk mendukung kinerja KPU Kota Makassar dapat dilihat dari segi kualitas layanan yang diberikan kepada masyarakat. Indikator ini dapat dilihat dari bagaimana KPU Kota Makassar dalam pemberian informasi dan kualitas sumber daya manusia yang mendukung dalam pelaksanaan tugas. Dengan melihat proses tersebut, penulis dapat menganalisis apakah pemberian informasi dan kualitas sumber daya manusia sudah sesuai yang diinginkan.

Pemberian informasi merupakan bagaimana cara menyampaikan suatu pesan kepada orang lain sehingga pesan tersebut dapat dipahami dan dilaksanakan. Dalam hal ini bagaimana dan apa yang dilakukan KPU Kota Makassar agar khususnya masyarakat pendatang yang ada di Kota Makassar dapat menggunakan hak suara pada saat Pilpres. KPU Kota Makassar dalam memberikan informasi kepada masyarakat pendatang melakukan berbagai cara sosialisasi baik secara langsung, online, maupun media massa dan memberikan informasi mengenai batas waktu yang telah ditentukan untuk mendaftarkan diri sebagai DPTb di Kota Makassar.

Kualitas Sumber Daya Manusia merupakan mutu dari tenaga kerja yang menyangkut kemampuan pada saat bekerja. Untuk melihat bagaimana kualitas SDM yang ada di KPU Kota Makassar dan Badan Penyelenggara, maka harus mengikuti tahapan mekanisme yang telah ditetapkan dalam PKPU Nomor 25 Tahun 2018 tentang Perubahan Atas Peraturan Komisi Pemilihan Umum Nomor 7 Tahun 2018 tentang Seleksi Anggota Komisi Pemilihan Umum Provinsi dan Komisi Pemilihan Umum Kabupaten/ Kota.Begitu panjang proses yang harus dilalui untuk bisa menjadi bagian anggota KPU Kota Makassar dan Badan Penyelenggara.

\section{Responsivitas}

Kemampuan birokrasi untuk mengenali kebutuhan masyarakat, menyusun agenda dan prioritas pelayanan serta mengembangkan program-program pelayanan. Indikator tersebut dapat dilihat dari bagaimana daya tangkap KPU dan Badan Penyelenggara dalam memberikan pelayanan dan apa keinginan masyarakat dalam penyelenggaraan Pilpres.

Daya Tangkap merupakan kemampuan memahami apa yang diterima dan bagaimana memberikan pelayanan kepada masyarakat. KPU Kota Makassar mengadakan pelatihan orientasi tugas kepada anggota KPU dan Badan Penyelenggara agar memahami perannya sebelum melayani masyarakat.

Keinginan Masyarakat merupakan harapan masyarakat terhadap apa yang akan dilakukan Pemerintah khususnya KPU Kota Makassar kepada masyarakat. Harapan masyarakat dalam hal ini adalah agar dapat menggunakan hak suaranya pada saat 
pemilu dan ketika tidak berada di daerahnya karena tugas ataupun hal yang lain.

\section{Responsibilitas}

KPU Kota Makassar dalam melaksanakan kegiatannya diharapkan sesuai dengan target yang akan dicapai serta berdasarkan prinsipprinsip administrasi pelayanan dengan baik dalam menggunakan sistem layanan. Untuk melihat bagaimana responsibilitas KPU Kota Makassar, penulis menganalisis dengan menjabarkan bagaimana tanggung jawab dan kerja sama yang dilakukan dengan stakeholder guna menciptakan kesesuain dalam mencapai tujuan.

Tanggung Jawab adalah kesediaan untuk menyiapkan diri dalam menghadapi masyarakat dan proses prosedur dari awal sampai akhir sehingga apa yang diharapkan bisa tercapai. KPU Kota Makassar dalam hal ini sudah melakukan langkah-langkah dalam melayani masyarakat pendatang agar bisa menggunakan hak suaranya pada Pilpres 2019 di Kota Makassar karena masih ada masyarakat yang belum menerima informasi sehingga tidak dapat menggunakan hak suaranya.

Kerja sama adalah menjalin kemitraan dengan orang atau suatu organisasi tertentu dengan tujuan yang sama. Kerja sama yang dilakukan KPU Kota Makassar bertujuan untuk memudahkan pemenuhan kebutuhan dalam pelaksanaan pilpres dan juga untuk meminimalisasi permasalahan di lapangan pada pelaksanaan. Adapun untukpemenuhan kebutuhan logistik pelaksanaan Pilpres 2019 KPU Kota Makassar bekerja sama dengan PT. Manyingarri. Untuk keamanan dan ketertiban pelaksanaan Pilpres 2019 KPU Kota Makassar bekerja sama dengan Satpol PP Kota Makassar dan Pihak Kepolisian untuk membantu penjagaan selama Pilpres.

\section{Akuntabilitas}

Dalam kinerjanya, KPU Kota Makassar memiliki suatu ukuran yang menunjukkan seberapa besar tingkat kesesuaian penyelenggaraan pelayanan yang dilaksanakan. Dalam hal ini, KPU Kota Makassar sudah melaksanakan seluruh mekanisme yang telah diatur oleh KPU Pusat dalam penyelenggaraan Pilpres 2019, penetapan data DPTb, dan ada beberapa kebijakan yang diambil oleh KPU Kota Makassar namun tetap berpedoman pada aturan yang sudah ditetapkan.

Tingkat Kesesuaian merupakan kemampuan memahami apa yang diterima dan bagaimana memberikan pelayanan. KPU Kota Makassar telah mengadakan pelatihan orientasi tugas kepada anggota KPU dan Badan Penyelenggara agar memahami perannya sebelum melayani masyarakat khususnya masyarakat pendatang, sehingga meminimalkan kesalahan yang terjadi di lapangan dalam pelaksanaan tugasnya.

Tindakan merupakan keputusan yang diambil dalam menghadapi suatu persoalan yang terjadi. Tindakan yang diambil KPU Kota Makassar khususnya yang terkait dengan masyarakat pendatang yang baru pada $\mathrm{H}$ ingin menggunakan hak suaranya datang ke TPS, tetap mengacu pada aturan yang sudah ada.

\section{Kinerja KPU Kota Makassar dalam Meningkatkan Partisipasi Masyarakat Pendatang Pada Pilpres 2019}

Berdasarkan pengamatan di lapangan, kinerja KPU Kota Makassar dalam Meningkatkan partisipasi masyarakat pendatang pada Pilpres 2019 dapat dilihat dari tahapan-tahapan yang telah dilaksanakan selama Pilpres, baik sebelum maupun sesudahnya. Tahapan-tahapan tersebut antara lain sebagai berikut.

\section{- Sosialisasi}

Berikut adalah proses sosialisasi yang dilakukan KPU Kota Makassar kepada masyarakat pendatang di Kota Makassar agar mereka dapat mendaftarkan dirinya sebagai DPTb pada Pilpres sebagaimana tampak pada tabel 4 . 
Tabel 4 Proses Sosialisasi Kepada Masyarakat Pendatang

\begin{tabular}{cllll}
\hline \multirow{2}{*}{ No } & \multicolumn{2}{c}{ KPU Kota Makassar } & \multicolumn{2}{c}{ Badan Penyelenggara (Ad hoc) } \\
\cline { 2 - 5 } & \multicolumn{1}{c}{ Proses } & \multicolumn{1}{c}{ Target Group } & \multicolumn{1}{c}{ Proses } & Target Group \\
\hline 1. & $\begin{array}{l}\text { Penentuan jadwal } \\
\text { sosialisasi }\end{array}$ & $\begin{array}{l}\text { Dilaksanakan sesuai } \\
\text { kondisi di lapangan }\end{array}$ & - \\
2. & $\begin{array}{l}\text { Dilaksanakan secara formal } \\
\text { dengan mengumpulkan }\end{array}$ & Mahasiswa, Pegawai & Dilaksanakan secara non & Masyarakat \\
& palon DPTb secara forum & & formal dan langsung & di Kelurahan \\
3. & Dilaksanakan oleh Divisi & Tempat umum, & Dilaksanakan oleh PPS di & RT, RW \\
& Partisipasi Masyarakat & media sosial, & Kelurahan & \\
\end{tabular}

\section{- Pendataan}

Ada dua langkah yang diberikan oleh KPU Kota Makassar kepada masyarakat pendatang terkait proses pendataan, yaitu sebagai berikut.

1. Bagi masyarakat yang tidak dapat mendaftarkan dirinya ke KPU Kota Makassar, bisa melapor ke RT/RW setempat, selanjutnya RT/RW setempat yang membantu untuk pendaftaran dan penerbitan formulir A5 yang akan digunakan pada saat pemilihan.

2. Bagi masyarakat yang datang langsung ke kantor KPU Kota Makassar, tersedia loket dan bisa langsung mendapatkan formulir A5. Mereka cukup memperlihatkan $e$-KTP atau surat keterangan domisili dari kelurahan setempat. Selanjutnya, KPU Kota Makassar yang akan memverifikasi ke TPS yang sudah terdaftar di daerah sebelumnya. Kemudian diproses sampai terdaftar di database KPU Kota Makassar sebagai DPTb.

KPU Kota Makassar dalam kinerjanya mengakomodir hak politik seluruh masyarakat pendatang yang memenuhi syarat, melakukan hingga tiga kali perbaikan data. Hal tersebut dalam rangka memberikan pelayanan yang maksimal terhadap masyarakat pendatang yang pindah memilih meski dengan ketentuan persyaratan yang ada.

\section{- Pelaksanaan}

Pada saat hari pelaksanaan Pilpres, yang berperan di TPS untuk melayani DPTb adalah KPPS. Berikut alur pelaksanaan memilih bagi DPTb, yaitu sebagai berikut.

- Bagi DPTb yang hadir untuk berpartisipasi memilih, terlebih dahulu melakukan registrasi agar bisa memilih, di mana pada saat registrasi tersebut panitia membedakan formulir untuk pendaftaran ulang bagi DPTb yang sudah datang, sehingga dapat dibedakan mana masyarakat yang terdaftar sebagai DPTb atau bukan.

- Bagi masyarakat pendatang yang belum terdaftar namun datang pada saat hari pelaksanaan, ada kebijakan yang diberikan untuk dapat menggunakan hak suaranya namun tetap dilihat kriteria yang dapat diberikan, misalnya H-1 pelaksanaan mendapatkan tugas ke daerah tersebut dengan memperlihatkan $e$-KTP, Surat Tugas selanjutnya bersedia untuk menunggu. Mereka dapat menggunakan hak suaranya ketika seluruh DPTb telah menggunakan hak suaranya dan apabila ada kelebihan kertas suara atau di atas pukul 13.00 dapat menggunakan hak suaranya.

Dariprosespelaksanaandilapanganinilah dapat diketahui bagaimana kinerja Badan Penyelenggara yang sangat berpengaruh pada tingkat partisipasi pemilih DPTb yang berasal dari masyarakat pendatang. 


\section{Faktor-Faktor yang Memengaruhi Kinerja KPU Kota Makassar dalam Meningkatkan Partisipasi Masyarakat Pendatang pada Pilpres 2019}

Berdasarkan pengamatan di lapangan mengenai kinerja KPU Kota Makassar dalam Meningkatkan partisipasi masyarakat pendatang pada Pilpres 2019, dipengaruhi oleh beberapa faktor yang dikelompokkan menjadi dua bagian, yaitu faktor pendukung dan faktor penghambat.

\section{- Faktor Pendukung}

Berdasarkan hasil pengamatan di lapangan, faktor pendukung ini dilihat dari halhal yang dapat mendukung suksesnya kinerja KPU Kota Makassar dalam Meningkatkan partisipasi masyarakat pendatang pada Pilpres 2019. Terdapat tiga faktor yang mendukung, di antaranya sebagai berikut.

\section{a. Faktor Personel/Individu}

Faktor personel/individu yang dimaksud meliputi pengetahuan, keterampilan (skill), kemampuan, kepercayaan diri, motivasi, dan komitmen yang dimiliki setiap anggota KPU Kota Makassar. Anggota KPU Kota Makassar telah mengikuti berbagai tahapan seleksi sebelum diangkat secara resmi, dan setelah ditetapkan sebagai anggota, juga mengikuti pelatihan. Selain itu, untuk meningkatkan wawasan dan kemampuan Badan Penyelenggara/ad hoc untuk memahami tugasnya, diadakan bimbingan teknis agar pelaksanaan di lapangan berjalan tanpa hambatan. Dengan adanya kegiatan-kegiatan tersebut, maka kemampuan KPU Kota Makassar dan Badan Penyelenggara menjadi salah satu faktor pendukung dalam meningkatkan partisipasi masyarakat pendatang pada Pilpres.

\section{b. Faktor Tim}

Faktor tim yang dimaksud dalam hal ini meliputi kualitas dukungan dan semangat yang diberikan oleh rekan dalam satu tim, kepercayaan terhadap sesama anggota tim, kekompakan dan keeratan anggota tim. Pelaksanaan Pilpres harus disukseskan oleh kerja sama, baik di lingkup KPU Kota Makassar maupun di lingkup Badan Penyelenggara/ad hoc, khususnya KPPS.

Selain kerja sama secara internal organisasi, KPU Kota Makassar dan Badan Penyelenggara juga bekerja sama secara eksternal, yaitu dengan pihak ketiga dalam hal pengadaan barang, dan dengan instansi terkait pengamanan dan ketertiban dalam hal jasa, yaitu kepolisian dan linmas. Sebagai unsur pendukung dalam suksesnya pelaksanaan Pilpres, maka faktor tim yakni kerja sama yang dijalin oleh KPU Kota Makassar telah berjalan dengan lancar.

\section{c. Faktor Sistem}

Faktor sistem yang menyangkut kinerja KPU Kota Makassar dalam Meningkatkan partisipasi masyarakat pendatang, yaitu anggaran. KPU Kota Makassar dalam menjalankan kinerjanya di setiap tahapan kegiatan pelaksanaan Pilpres, tidak terlepas dari kebutuhan pembiayaan berupa anggaran yang bersumber dari APBN. Anggaran yang disiapkan telah memadai dan mencukupi untuk mendukung seluruh tahapan kegiatan selama persiapan dan pelaksanaan Pilpres, artinya dengan nominal 5,15 Milyar rupiah yang dikelola oleh KPU Kota Makassar, hampir tidak menimbulkan masalah terkait keuangan.

\section{- Faktor Penghambat}

Berdasarkan pengamatan di lapangan, faktor penghambat dilihat dari segala sesuatu yang dapat menghambat kelancaran kinerja KPU Kota Makassar dalam Meningkatkan partisipasi masyarakat pendatang pada Pilpres 2019. Terdapat dua faktor yang 
mendukung, di antaranya sebagai berikut.

\section{a. Faktor Sistem}

Faktor sistem dalam hal ini adalah fasilitas kegiatan, di mana sarana dan prasarana yang belum terpenuhi dengan baik dapat menjadi faktor penghambat kegiatan. Pada pelaksanaan Pilpres 2019, KPU Kota Makassar kekurangan kertas suara untuk DPTb. Hal ini berpengaruh pada tingkat partisipasi masyarakat pendatang pada Pilpres 2019 sehingga kinerja KPU dinilai kurang maksimal.

Selain itu, sosialisasi merupakan kegiatan awal yang dilakukan oleh KPU Kota Makassar dalam Meningkatkan tingkat partisipasi masyarakat pendatang pada Pilpres 2019. Dalam proses pelaksanaan sosialisasi dinilai masih terdapat kekurangan, hal ini dapat dilihat dari data tabel 5 .

Tabel 5 Daftar Masyarakat Pendatang di Kota Makassar Tahun 2019

\begin{tabular}{clcc}
\hline No & \multicolumn{1}{c}{ Keterangan } & $\begin{array}{c}\text { Jumlah } \\
\text { (orang) }\end{array}$ \\
\hline 1. & Yang terdaftar & 7.267 \\
2. & $\begin{array}{l}\text { Yang menggunakan hak } \\
\text { suaranya }\end{array}$ & 6.106 \\
\hline 3. & $\begin{array}{l}\text { Yang tidak menggunakan } \\
\text { hak suaranya }\end{array}$ & 1.161 \\
\hline
\end{tabular}

Sumber: KPU Kota Makassar 2020

Dilihat dari data tabel 5, masih terdapat masyarakat pendatang yang sudah terdaftar namun tidak menggunakan hak suaranya sejumlah 1.161 orang. Hal ini terjadi karena KPU belum bisa mendata secara keseluruhan dan masih banyak masyarakat pendatang yang belum mendapat informasi. KPU Kota Makassar tidak melaksanakan sosialisasi secara merata ke seluruh elemenelemen masyarakat karena keterbatasan waktu.

\section{b. Faktor Kontekstual}

Faktor kontekstual (situasional), meliputi tekanan dan perubahan lingkungan eksternal dan internal pada pelaksanaan Pilpres. Kuantitas SDM merupakan faktor penting dalam menjalankan suatu kegiatan, namun pada pelaksanaan Pilpres terdapat tekanan dari pihak masyarakat pendatang yang ingin dilayani sehingga berpengaruh pada kekurangan personel. KPU Kota Makassar dalam hal ini masih sangat kekurangan jumlah personel melihat banyaknya warga masyarakat yang harus dilayani. Di samping itu jumlah personel KPU Kota Makassar hanya 38 orang tidak sebanding dengan jumlah masyarakat yang ada di Kota Makassar.

Selain itu, faktor eksternal lain, yaitu data. Data merupakan catatan atas kumpulan fakta. Data inilah dijadikan salah acuan untuk melihat angka tingkat partisipasi masyarakat pendatang. Untuk data masyarakat pendatang belum ada database yang dibuatkan oleh KPU Kota Makassar maupun belum sinkron data yang ada di Dinas Kependudukan dan Catatan Sipil. Hal ini disebabkan karena masyarakat pendatang tidak bisa diprediksi berapa tahun dia berada di Kota Makassar. Oleh karena itu, untuk data masyarakat pendatang harus dicari dan didata setiap ingin melaksanakan kegiatan agar datanya akurat. Beda halnya dengan DPT Kota Makassar, data tersebut sudah sinkron dengan Dukcapil Kota Makassar sehingga tidak harus mendata ulang.

\section{Upaya yang Dilakukan KPU Kota Makassar}

Upaya adalah tindakan yang dilakukan oleh seseorang atau kelompok dengan segenap daya dan harapan untuk mengatasi masalah dalam mencapai suatu tujuan yang telah ditentukan sebelumnya dengan berbagai cara, teknik dan metode yang dilakukan 
dengan segenap kemampuan yang ada untuk mencapai tujuan tersebut.

Upaya-upaya yang dilakukan dalam mengatasi hambatan-hambatan tersebut adalah antara lain sebagai berikut.

1. KPU Kota Makassar tidak hanya melakukan sosialisasi secara langsung, namun dengan berbagai cara dilakukan di antaranya melalui media sosial, media massa, media cetak, kegiatan keagamaan dan kegiatan sosial. Lebih meningkatkan sosialisasi berbagai cara dan tanpa mengenal waktu. Hari libur pun digunakan untuk sosialisasi karena keterbatasan waktu.

2. Melakukan perbaikan data hingga tiga kali antara lain: proses rekap pertama bulan februari 2019; proses rekap kedua bulan Maret 2019; dan proses rekap ketiga bulan April 2019 dengan mengundang seluruh parpol, media, Bawaslu, dinas terkait dalam rangka membahas DPTb. Hal tersebut dilakukan agar data DPTb valid sehingga surat suara yang disediakan tidak mengalami kekurangan.

3. KPU Kota Makassar membentuk Badan Penyelenggara yang terdiri dari PPK, PPS, dan KPPS untuk membantu KPU dalam melaksanakan tugas. Selain itu KPU Kota Makassar membentuk tim relawan, LSM, karang taruna yang bersedia untuk membantu dalam melaksanakan sosialisasi. Selain itu KPU Kota Makassar bersama Badan Penyelenggara PPK, PPS dan dibantu oleh RT RW turun langsung ke rumah rumah warga untuk melakukan pendataan. Membentuk relasi (relawan demokrasi) dalam rangka menjaring sejumlah relawan sebagai pemberi informasi. Hal-hal tersebut untuk mengatasi adanya kekurangan personel untuk melayani masyarakat pendatang.

\section{SIMPULAN}

Berdasarkan hasil penelitian dan pembahasan yang telah dikemukakan pada bab sebelumnya, dapat diambil simpulan sebagai berikut.

Pertama, Kinerja KPU Kota Makassar dalam Meningkatkan partisipasi masyarakat pendatang pada Pilpres 2019 belum mencapai 100\%. Hal ini didasarkan atas wawancara yang dilakukan terhadap pihakpihak yang terkait dengan kinerja KPU Kota Makassar, dan pembahasan dari indikatorindikator yang berpengaruh dengan Kinerja KPU Kota Makassar dalam Meningkatkan partisipasi masyarakat pendatang pada Pilpres 2019, yaitu sebagai berikut.

- Secara produktivitas, KPU Kota Makassar mampu mengelola aspekaspek yang dimiliki secara efisien namun belum efektif, ditunjukkan dengan kemampuan cukupnya anggaran dari APBN sebesar Rp 5.150.000.000, telah tertib dalam menjalankan SOP untuk masyarakat pendatang yang ditetapkan melalui PKPU Nomor 37 Tahun 2018, belum memiliki inisiatif untuk membuat program tambahan yang berfokus pada masyarakat pendatang, dan adanya kekurangan surat suara di beberapa TPS sehingga banyak DPTb yang tidak bisa menggunakan hak suaranya.

- Secara kualitas layanan, KPU Kota Makassar telah memiliki keandalan, daya tanggap, jaminan, empati, dan bukti fisik atau langsung, yang bisa dilihat dalam memberikan informasi kepada masyarakat pendatang yakni melakukan berbagai cara sosialisasi.

- Secara responsivitas, pemberian informasi yang diharapkan melalui sosialisasi belum meluas ke seluruh unsur masyarakat.

- Secara responsibilitas, tanggung jawab KPU Kota Makassar dalam melaksanakan tanggung jawabnya masih sebatas 
melayani masyarakat pendatang yang datang dan ingin dilayani, belum ada inisiatif untuk menjemput bola dalam artian datang kepada masyarakat untuk memberikan pelayanan.

- Secara akuntabilitas, tingkat kesesuaian dan validitas data bisa berubah sampai hari H pelaksanaan. Hal ini terjadi karena kondisi masyarakat yang cenderung dinamis dan bisa berubah karena suatu faktor.

Pada umumnya indikator-indikator tersebut mengalami hambatan-hambatan dan menjadi faktor penghambat pada kinerja KPU Kota Makassar dalam Meningkatkan partisipasi masyarakat pendatang, akan tetapi hambatan-hambatan tersebut dapat diminimalkan supaya tidak mengganggu jalannya kinerja.

Kedua, faktor-faktor yang memengaruhi kinerja KPU Kota Makassar dalam Meningkatkan partisipasi masyarakat pendatang pada Pilpres 2019, yaitu personel yang terampil, anggaran yang tersedia, kerja sama yang baik, selain itu terdapat faktor penghambat yakni keterbatasan waktu, kekurangan surat suara, dan jumlah personel.

Ketiga, upaya yang dilakukan KPU Kota Makassar untuk mengatasi hambatan dalam meningkatkan partisipasi masyarakat pendatang pada Pilpres 2019 antara lain melakukan sosialisasi dengan berbagai cara dan tanpa mengenal waktu; membentuk tim relawan, LSM, karang taruna yang bersedia untuk membantu melayani masyarakat pendatang; perbaikan data hingga 3 kali dengan mengundang seluruh parpol, media, Bawaslu, dinas terkait dalam rangka membahas DPTb.

\section{SARAN}

Berkaitan dengan simpulan yang diuraikan di atas, maka penulis mengemukakan beberapa saran yakni KPU
Kota Makassar dalam mengatasi kendala yang muncul perlu mengambil langkah sebagai solusi atas masalah pada kinerja KPU Kota Makassar, antara lain sebagai berikut.

a. KPU Kota Makassar perlu mengemas lebih menarik pada kegiatan sosialisasi dan disesuaikan dengan karakteristik masyarakat, dan membuat jadwal pelayanan khusus tambahan di hari Sabtu dan Minggu untuk melayani masyarakat pendatang

b. Jajaran KPU Kota Makassar harus lebih transparan kepada masyarakat pendatang dan memberikan informasi yang akurat, agar pelayanan semakin baik dan semakin banyak masyarakat yang bisa didata dari jumlah sebelumnya.

c. Melihat teknologi semakin maju dan canggih, KPU Kota Makassar diharapkan dapat membuat suatu aplikasi online untuk pendaftaran masyarakat pendatang sehingga tidak harus ke Kantor KPU ataupun ke Kelurahan dan mengadakan TPS keliling khusus masyarakat pendatang agar memudahkan para masyarakat pendatang dapat menggunakan hak suaranya.

\section{DAFTAR PUSTAKA}

Abdulsyani. 2013. Sosiologi: Skematika, Teori, dan Terapan. Jakarta, PT. Bumi Aksara.

Adi, Isbandi, R. 2008. Intervensi Komunitas Pengembangan Masyarakat sebagai Upaya Pemberdayaan Masyarakat. Jakarta, PT. Raja Grafindo Persada.

Amins, Achmad. 2012. Manajemen Kinerja Pemerintahan Daerah. Yogyakarta, LaksBang PRESSindo.

Amirullah. 2015. Manajemen Strategi: TeoriKonsep-Kinerja. Jakarta, Mitra Wacana Media.

Arikunto, Suharsimi. 2010. Prosedur Penelitian Suatu Pendekatan Praktik. Jakarta, Rineka cipta. 
Dessler, Gary. 2010. Manajemen Sumber Daya Manusia, Penerjemah: Eli Tanya. Jakarta, Index.

Dwiyanto dkk, Agus. 2008. Reformasi Birokrasi Publik di Indonesia. Yogyakarta, Gajah Mada University Press.

Herdiansyah, Haris. 2013. Wawancara Observasi dan Fokus Groups Sebagai Instrumen Penggalian Data Kualitatif. Jakarta, Rajawali Press.

Karianga, Hendra. 2011. Partisipasi Masyarakat Dalam Mengelola Keuangan Daerah (Perspektif Hukum dan Demokrasi). Bandung, PT. Alumni.

Koentjaraningrat. 2009. Pengantar Ilmu Antropologi. Jakarta, Rineka Cipta.

Mahmudi, 2010. Manajemen Kinerja Sektor Publik. Sekolah Tinggi Ilmu Manajemen YKPN.

Mangkunegara, Prabu, A.A. 2010. Evaluasi Kinerja SDM. Bandung, Refika Aditama.

Moleong, Lexy J. 2012. Metode Penelitian Kualitatif. Bandung, Remaja Rosdakarya.

Nasution. 2011. Teknologi Pendidikan. Jakarta, Bumi Aksara.

Nazir. 2013. Metode Penelitian. Bogor, Ghalia Indonesia.

Ndraha, T. 2011. Kybernology (Ilmu Pemerintahan Baru). Jakarta, PT Rineka Cipta.

Sedarmayanti. 2011. Manajemen Sumber Daya Manusia: Reformasi Birokrasi dan Manajemen Pegawai Negeri Sipil. Bandung, Refika Aditama.

Sinambela, Lijan Poltak. 2012. Kinerja Pegawai Teori Pengukuran dan Implikasi. Yogyakarta, Graha Ilmu.

Sudarmanto. 2009. Kinerja dan Pengembangan Kompetensi. Yogyakarta, Pustaka Belajar.

Sugiyono. 2012. Metode Penelitian Kualitatif. Bandung, Alfabeta.

Sugiyono. 2013. Metode Pendidikan Penelitian. Bandung, Alfabeta.

Suharsaputra, Uhar. 2012. Metode Penelitian: Kuantitatif, Kualitatif dan Tindakan. Bandung, PT. Refika Aditama.
Sutopo. 2006. Metodologi Penelitian Kualitatif. Surakarta, UNS.

Soekanto, Soerjono. 2012. Sosiologi Suatu Pengantar. Jakarta, Rajawali Pers.

Wirawan. 2012. Evaluasi Kinerja Sumber Daya Manusia (Teori, Aplikasi, dan Penelitian). Jakarta, Salemba Empat.

\section{Penelitian Terdahulu}

Willians Gratiano Timpal 2014. Peran Komisi Pemilihan Umum dalam Menangani Pemilih Khusus Tambahan pada Pemilihan Umum Presiden dan Wakil Presiden Tahun 2014 di Kota Tomohon. Skripsi.

E. Anusapati 2014. Kinerja Aparatur Komisi Pemilihan Umum Kabupaten Kubu Raya. Tesis.

Tohap Hasugian 2018. Strategi Komisi Pemilihan Umum dalam Meningkatkan Partisipasi Pemilih (Studi Pemilih Pemula, Perempuan dan Kelompok Marjinal pada Pemilihan Bupati dan Wakil Bupati Tahun 2018 di Kabupaten Dairi Provinsi Sumatera Utara). Tesis.

\section{Peraturan Perundang-Undangan}

Undang-Undang Dasar Negara Kesatuan Republik Indonesia Tahun 1945

Undang-Undang Nomor 42 Tahun 2008 tentang Pemilihan Umum Presiden dan Wakil Presiden

Undang-Undang Nomor 7 Tahun 2017 tentang Pemilihan Umum

Peraturan KPU Nomor 11 Tahun 2018 tentang Penyusun Daftar Pemilih di Dalam Negeri Dalam Penyelenggaraan Pemilihan Umum

Peraturan KPU Nomor 37 Tahun 2018 tentang Penyusunan Daftar Pemilih Dalam Negeri

\section{Website}

https://kota-makassar.kpu.go.id

http://harnas.co/2019/04/10/dpt-dan-dptbsudah-final

h t t p s : / / w w w. c n n ind on esia.com / nasional/20190417145018-32-387241/ pemilih-tambahan-di-makassar-banyaktak-dapat-surat-suara 